Only few studies except those of BRETIE and LoUgnoN (1969) have been devoted to the feeding of pigs with rich protein wheat. The wheat used by these authors belonged to the spring variety "Sonora 64 " containing $200 \mathrm{~g}$ protein $/ \mathrm{kg}$ dry matter. Because of the positive results obtained we decided to examine how to obtain rich protein wheat with the highest yielding winter varieties, especially those unfitted for bread making or of poor baking capacity. Parallel to that, some of the wheat lots were used in animal trials. Those concerning bacon pigs will be reported here.

- In the first trial, the formulation of the experimental diets according to the lysine content only, did not lead to a saving of soybean meal, but showed that this type of wheat allowed to obtain the same performances (average daily gain, feed conversion ratio) as those observed with more current wheat varieties and that the carcass quality was improved.

- In the two other trials, use of industrial lysine led to a soybean saving increasing with the protein content of the wheat; thus, lysine appeared to be the first limiting amino acid. In the third trial performed with a particularly rich wheat (I 7.4 p. Ioo protein in the dry matter) one of the diets used contained only wheat, supplemented with lysine and a vitamin-mineral mixture. The performances obtained were highly variable (average daily gain, 67I g; feed conversion ratio $3.20 \mathrm{~kg}$ feed $/ \mathrm{kg}$ gain). This is naturally an extreme case, but this experiment clearly shows that it is possible to valorize rich protein wheat and to save soybean meal.

\title{
Digestibility of horse-beans containing tannins or not by the growing pig
}

\author{
P.-H. DUÉE, D. BOURDON, L. GUILBAULT, Régine CAIMAES, J. MARTIN-TANGUY \\ Station de Recherches sur l'Élevage des Porcs, \\ Centre national de Recherches zootechniques, I.N.R.A., \\ 78350 Jouy-en-Josas (France)
}

A study was carried out on I 2 castrated male pigs of $25 \mathrm{~kg}$ mean weight kept in metabolistn crates in order to compare the apparent digestibility and metabolic utilization of two horsebean varieties, the Rovasse horse-beans and a variety poor in tannins, to that of the soybean meal 44. These feeds constituted the only nitrogen sources and were incorporated into semipurified diets as replacers of variable proportions of maize starch so as to obtain the samie crude protein contents. Moreover the soybean and horse-bean diets were supplemented with $0.05 \mathrm{p}$. Ioo and $0.15 \mathrm{p}$. Ioo $\mathrm{DL}$-methionine, respectively.

These varieties of horse-beans differ mainly in their tannin contents $(3 \times 7.3 \mathrm{mg}$ for Io $\mathrm{g}$ teguments in the Rovasse variety versus $6 . \mathrm{Ing}$ in the other one), and secondarily in their true cellulose contents (ro.94 p. Ioo dry matter in the Rovasse variety versus 9.8 p. Ioo in the other one).

The apparent digestibility of crude protein was lower in the animals fed the Rovasse horsebeans (77.I p. Ioo versus $88.6 \mathrm{p}$. Ioo for the soybean tneal). The replacement of horse-beans rich in tannins by horse-beans poor in taninins improved by 8 points the apparent digestibility of crude protein. The metabolic utilization of the nitrogen ingested was lower with diets containing horse-beans as compared to soybean meal.

The apparent digestibilities of the amino acids of the three nitrogen sources were estimated and it appeared that the digestibilities of arginine, histidine and glutamic acid were higher than that of nitrogen. On the contrary, threonine, valine, isoleucine, alanine and glycine had a lower digestibility. 